WSRC-STI-2007-00260

Revision 0

\title{
SALTSTONE BATCH 0 TCLP RCRA METAL RESULTS
}

\author{
A.D. Cozzi
}

June 2007

Environmental \& Chemical Process Technology Savannah River National Laboratory Aiken, SC 29808 
WSRC-STI-2007-00260

Revision 0

\section{DISCLAIMER}

This report was prepared by Westinghouse Savannah River Company (WSRC) for the United States Department of Energy under Contract No. DE-AC09-96SR18500 and is an account of work performed under that contract. Neither the United States Department of Energy, nor WSRC, nor any of their employees makes any warranty, expressed or implied, or assumes any legal liability or responsibility for the accuracy, completeness, or usefulness, of any information, apparatus, or product or process disclosed herein or represents that its use will not infringe privately owned rights. Reference herein to any specific commercial product, process, or service by trademark, name, manufacturer or otherwise does not necessarily constitute or imply endorsement, recommendation, or favoring of same by WSRC or by the United States Government or any agency thereof. The views and opinions of the authors expressed herein do not necessarily state or reflect those of the United States Government or any agency thereof.

\section{Printed in the United States of America \\ Prepared For \\ U.S. Department of Energy}


Key Words: Saltstone

TCLP

Retention: Permanent

\title{
SALTSTONE BATCH 0 TCLP RCRA METAL RESULTS
}

\author{
A.D. Cozzi
}

June 2007

Immobilization Technology Section Savannah River National Laboratory Aiken, SC 29808

Prepared for the U.S. Department of Energy Under Contract Number DEAC09-96SR18500

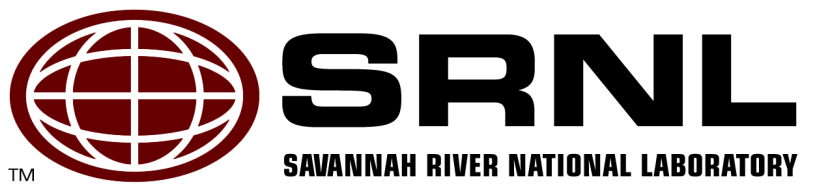


WSRC-STI-2007-00260

Revision 0

\section{REVIEWS AND APPROVALS}

\section{AUTHORS:}

A.D. Cozzi, Process Science and Engineering

Date

\section{TECHNICAL REVIEWER:}

R.E. Eibling, Process Science and Engineering

Date

\section{APPROVERS}

R. E. Edwards, Manager, Process Science and Engineering Date

D. A. Crowley, Manager, Stabilization Science Research

Date

J. E. Occhipinti, Manager, Waste Solidification Engineering

Date 


\subsection{EXECUTIVE SUMMARY}

A saltstone waste form was prepared in the Savannah River National Laboratory from a Tank $50 \mathrm{H}$ sample and Z-Area premix material. After the prescribed 28 day cure, samples of the saltstone were collected, and the waste form was shown to meet the South Carolina Hazardous Waste Management Regulations (SCHWMR) R.61-79.261.24 requirements for a nonhazardous waste form with respect to RCRA metals. These analyses met all quality assurance specifications of USEPA SW-846. 
TABLE OF CONTENTS

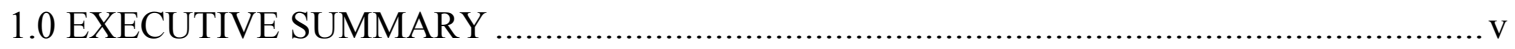

3.0 INTRODUCTION

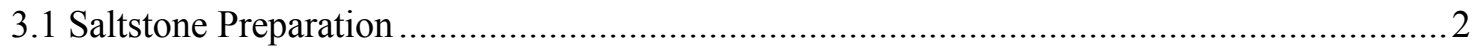

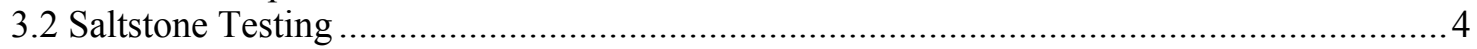

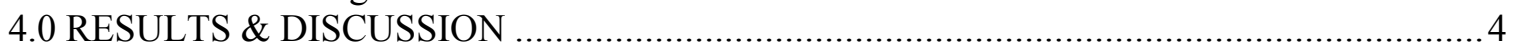

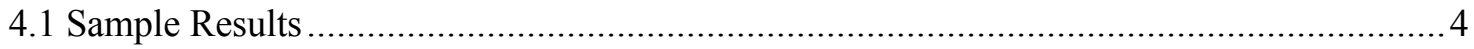

4.2 Comparison of Results to Regulatory Limits ..........................................................

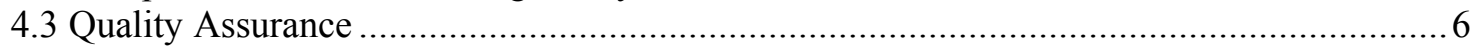

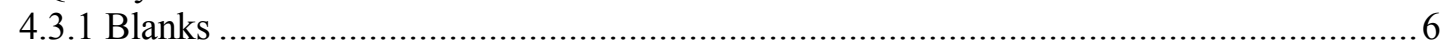

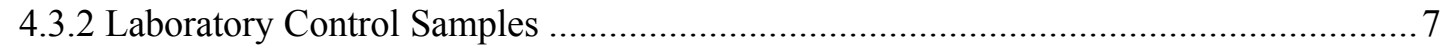

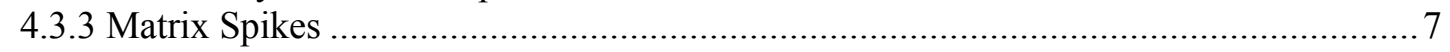

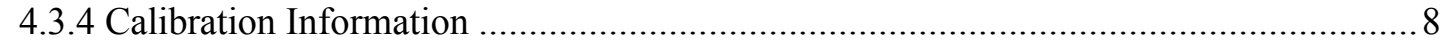

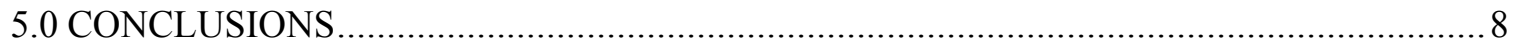

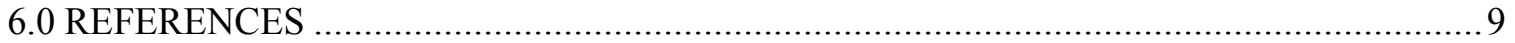




\section{LIST OF FIGURES}

Figure 1. Flowchart of saltstone sample preparation and analysis.........................................2

Figure 2. Data sheet for the saltstone mix used to prepare samples for TCLP........................... 3 


\section{LIST OF TABLES}

Table 1. Customer Recommended Values for Preparation of TCLP Samples. ............................. 2

Table 2. Sample Results of TCLP Metal from Tank 50 WAC Analysis in Reference 5 ............... 3

Table 3. TCLP Leachates RCRA Metal Concentrations, DLs, and RLs...................................5

Table 4 Saltstone TCLP Results and Corresponding Regulatory Limits. ............................... 6

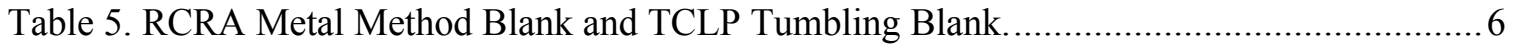

Table 6. RCRA Metal Laboratory Control Sample. ............................................................... 7

Table 7. TCLP Leachates RCRA Metal Matrix Spike and Duplicate Results. ............................. 7 


\section{LIST OF ACRONYMS}

$\begin{array}{ll}\text { DL } & \text { Detection Limit } \\ \text { ESS-WP } & \text { Environmental Services Section - Waste Programs } \\ \text { ETP } & \text { Effluent Treatment Project } \\ \text { ISWLF } & \text { Industrial Solid Waste Landfill } \\ \text { LCS } & \text { Laboratory Control Sample } \\ \text { MCL } & \text { Maximum Contaminant Level } \\ \text { MS } & \text { Matrix Spike } \\ \text { MSD } & \text { Matrix Spike Duplicate } \\ \text { RCRA } & \text { Resource Conservation and Recovery Act } \\ \text { RL } & \text { Reporting Limit } \\ \text { RPD } & \text { Relative Percent Differences } \\ \text { SCDHEC } & \text { South Carolina Department of Health and Environmental Control } \\ \text { SDF } & \text { Saltstone Disposal Facility } \\ \text { SDG } & \text { Sample Delivery Group } \\ \text { SPF } & \text { Saltstone Production Facility } \\ \text { SRNL } & \text { Savannah River National Laboratory } \\ \text { TCLP } & \text { Toxic Characteristic Leaching Procedure } \\ \text { UTS } & \text { Universal Treatment Standards }\end{array}$




\subsection{INTRODUCTION}

The Saltstone Production Facility (SPF) receives waste from Tank $50 \mathrm{H}$ for treatment. Tank $50 \mathrm{H}$ contains waste streams (i.e. H-Canyon low-activity waste and Effluent Treatment Project (ETP) waste) designated as Batch 0, which was processed for disposal in the Saltstone Disposal Facility (SDF) from 12/04/2006 through 02/13/2007. When the campaign completed with the transition to Batch $1 \mathrm{~A}$ with a transfer from Tank $23 \mathrm{H}$, Saltstone had processed over $149 \mathrm{kgal}$ of salt solution.

The Saltstone Grout Sampling plan provides the South Carolina Department of Health and Environmental Control (SCDHEC) with the chemical and physical characterization strategy for the salt solution which is to be disposed of in the Z-Area Industrial Solid Waste Landfill (ISWLF) during the processing of Batch $0 .{ }^{1}$ Prior to operation, the salt waste stream was sampled and grout samples prepared to determine the non-hazardous nature of the grout to meet the requirements of SCHWMR R.61-79.261.24(b).

SRNL was asked to prepare saltstone from a sample of Tank $50 \mathrm{H}$ obtained prior to the Batch 0 campaign to determine the non-hazardous nature of the grout. ${ }^{2}$ The sample was cured and shipped to GEL laboratory to perform the Toxic Characteristic Leaching Procedure (TCLP) and subsequent extract analysis on saltstone samples for the analytes required for the quarterly analysis saltstone sample. 
WSRC-STI-2007-00260

Revision 0

\section{EXPERIMENTAL}

This section is a summary of the approach taken to prepare and characterize the saltstone samples. The saltstone sample preparation was performed in SRNL. Saltstone sample characterization was performed at the GEL laboratory facility in Charleston, South Carolina. Figure 1 is a flowchart of the steps taken to prepare and characterize the saltstone samples.

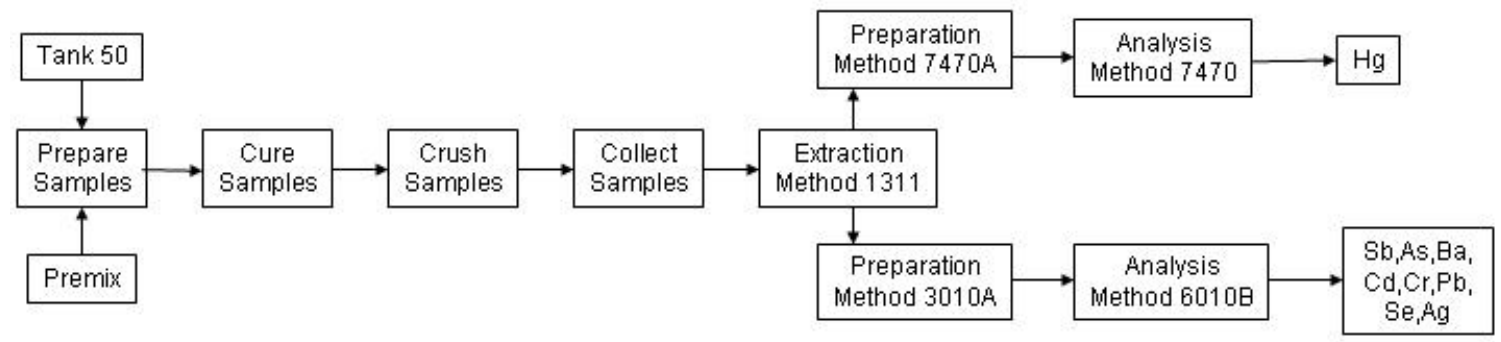

Figure 1. Flowchart of saltstone sample preparation and analysis.

\subsection{Saltstone Preparation}

Saltstone preparation was performed at SRNL. The weight percent solids data and the salt solution used for the TCLP samples were taken from the Batch 0 reconfirmation study. ${ }^{3}$ Table 1 contains the parameters recommended by the customer based on the work in Reference $3 .{ }^{4}$

Table 1. Customer Recommended Values for Preparation of TCLP Samples.

\begin{tabular}{|l|l|}
\hline Parameter & Value \\
\hline Water-to-Premix ratio & 0.63 \\
\hline Set Retarder (Daratard 17) & $0.27 \mathrm{~g} / 100 \mathrm{~g}$ premix \\
\hline Defoamer (Clean Air 100) & $0.14 \mathrm{~g} / 100 \mathrm{~g}$ premix \\
\hline "Clear" to "Murky" salt solution ratio & 1 \\
\hline
\end{tabular}

Equal portions of the "clear" and "murky" salt solution from Tank 50 that were used for the formulation reconfirmation work in Reference 3 were combined to make the salt solution for the TCLP sample. Table 2 lists the concentration TCLP metals of interest in the salt solution from the Waste Acceptance Criteria (WAC) analysis from the samples taken in September 2006. A complete analysis of the salt solution used is in Table 5 in Reference 5 . As can be gleaned from Table 2, mercury is the lone constituent positively identified above toxic levels. Saltstone samples for TCLP were prepared with the Tank $50 \mathrm{H}$ blended salt solution and a premix of cement, slag, and fly ash. Figure 2 shows the formulation used to prepare these samples. The salt solution, admixtures and premix materials were combined in a blender and mixed at low speed for one minute, inspected for incorporation of the premix, and then mixed at high speed for an additional two minutes. After the saltstone slurry was mixed, it was cast into glass bottles with Teflon lined lids to cure.

After curing for 28 days, the saltstone was removed from the container and a portion of the saltstone was crushed to articles less than 0.9 centimeters $(3 / 8 \mathrm{inch})$ as prescribed by Section 7.13 of the TCLP method. ${ }^{6}$ The crushed saltstone was packaged into containers provided by Environmental Services Section - Waste Programs (ESS-WP). ESS-WP collected the samples from SRNL and transported them to GEL laboratories ${ }^{*}$ for extraction and analysis.

${ }^{*}$ GEL Laboratories, LLC - Charleston, SC. 
Table 2. Sample Results of TCLP Metal from Tank 50 WAC Analysis in Reference 5

\begin{tabular}{|c||c|c||}
\hline \multicolumn{1}{|c||}{} & \multicolumn{2}{|c|}{ Sample Results (mg/L) } \\
\hline- & HTF-50-06-104-4 "clear" & HTF-50-06-104-6 "murky" \\
\hline $\mathrm{As}$ & $<0.832$ & $<0.832$ \\
\hline $\mathrm{Ba}$ & $<6.8$ & $<6.8$ \\
\hline $\mathrm{Cd}$ & $<18$ & $<18$ \\
\hline $\mathrm{Cr}$ & $<33$ & $<33$ \\
\hline $\mathrm{Pb}$ & $<173$ & $<173$ \\
\hline $\mathrm{Hg}$ & 10.3 & 23.9 \\
\hline $\mathrm{Se}$ & $<1.6$ & $<1.6$ \\
\hline $\mathrm{Ag}$ & $<13$ & $<13$ \\
\hline
\end{tabular}

Saltstone Mix Data Sheet

\begin{tabular}{|c|c|c|c|}
\hline \multicolumn{2}{|l|}{ MIX \# 0069} & \multicolumn{2}{|c|}{ Date: $\quad 12 / 20 / 2006$} \\
\hline Material & $\%$ & WT\% & Grams \\
\hline Waste Solution: Tank 50 Batch 0 & & \multirow{3}{*}{47.30} & \multirow{3}{*}{410.00} \\
\hline Wt $\%$ Solids \# 30.2 & & & \\
\hline Grams Water $\quad 286.18$ & & & \\
\hline Admixture: $\quad$ Daratard 17 & & 0.14 & 1.23 \\
\hline Admixture: $\quad$ Clear Air 100 & & 0.07 & 0.64 \\
\hline \multicolumn{4}{|l|}{ Admixture: } \\
\hline Premix & & 52.49 & 455.00 \\
\hline Cement ( $\%$ of Premix) & 10 & 5.25 & 45.50 \\
\hline Slag ( $\%$ of Premix) & 45 & 23.62 & 204.75 \\
\hline Fly Ash (\% of Premix) & 45 & 23.62 & 204.75 \\
\hline Total & 100 & 100 & 866.87 \\
\hline Water to Premix Ratio & \multicolumn{2}{|c|}{0.63} & \\
\hline \multicolumn{4}{|l|}{$\begin{array}{l}\text { Calculations: } \\
\text { wt \% solids from WSRC-TR-2006-00226 Revis } \\
205.3 \text { g HTF-50-06-102-4 "clear" } \\
205.3 \text { g HTF-50-06-102-6 "murky" } \\
\text { W/P } 0.63 \\
\text { Daratard } 170.27 \text { wt\% of premix } \\
\text { Clear Air } 0.14 \text { wt } \% \text { of premix }\end{array}$} \\
\hline
\end{tabular}

Figure 2. Data sheet for the saltstone mix used to prepare samples for TCLP. 


\subsection{Saltstone Testing}

Saltstone testing was performed by GEL Laboratories, LLC. Activities associated with the saltstone testing were:

- performing the TCLP extraction on the Tank 50 grout samples,

- digesting the TCLP leachate,

- analyzing the digested leachate.

The samples arrived at GEL Laboratories LLC, Charleston, South Carolina on January 31, 2007 for analysis. Shipping container temperatures were documented to be within specifications. The samples were delivered with proper chain of custody documentation and signatures. All sample containers arrived without any visible signs of tampering or breakage.

The sample and associated matrix quality control were prepared at a $10 \mathrm{x}$ factor to minimize potential interferences arising from the high sodium content in the TCLP leaching solution. Less than the specified $100 \mathrm{~g}$ of sample were extracted by EPA method 1311 because the samples were classified as RADII. The volume of extraction fluid used was adjusted accordingly.

Leachate from the composite sample was split into a duplicate sample, matrix spike and matrix spike duplicate. At this point, the laboratory had a sample, duplicate, triplicate, matrix spike, and matrix spike duplicate. An aliquot of each was taken for the USEPA SW-846 Method 7470A mercury digestion and analysis. The remainder of the samples and spikes was digested by Method 3010A and analyzed by Method 6010B for arsenic, barium, cadmium, chromium, lead selenium, and silver.

\subsection{RESULTS \& DISCUSSION}

\subsection{Sample Results}

Results were summarized in Table 3 from the data package for these analyses. ${ }^{7}$ Analytes detected but at concentrations too low to determine quantitatively have been flagged with the "J" qualifier. Analytes that were not detected have been flagged with the "U" qualifier. In addition to the results, Detection Limits (DLs) and Reporting Limits (RLs) have been given. The DL is the minimum concentration of an analyte that can be identified, measured, and reported with $99 \%$ confidence that the concentration is above zero. The DL values given in the table are the results from this study adjusted for sample dilution. The RLs given in Table 3 are five to ten times the DLs. The RL is the lowest level at which an analyte may be accurately and reproducibly quantitated.

Results in Table 3, when compared with the DLs and RLs, can be organized into three groups:

- Arsenic, cadmium, mercury, and silver were not detected in any leachates.

- Lead and selenium were detected below the RLs.

- Barium and chromium were detected in all leachates at concentrations above the RLs. 
WSRC-STI-2007-00260

Revision 0

Table 3. TCLP Leachates RCRA Metal Concentrations, DLs, and RLs.

\begin{tabular}{|c||c||c|c||c|c|c|}
\hline \multicolumn{1}{|c||}{} & \multicolumn{1}{|c||}{ Methods } & \multicolumn{2}{c||}{ Sample Limits (mg/L) } & \multicolumn{3}{c|}{ Sample Results (mg/L) } \\
\hline- & - & DL & RL & Sample 1 & Sample 2 & Average \\
\hline \hline Date & - & - & - & $01 / 30 / 07$ & $01 / 30 / 07$ & - \\
\hline SRS ID & - & - & - & Batch 0-A & Batch 0-B & - \\
\hline GEL ID & - & - & - & 179997001 & 179997002 & - \\
\hline \hline $\mathrm{As}$ & $3010 \mathrm{~A}, 7060 \mathrm{~B}$ & 0.06 & 0.15 & ${ }^{\mathrm{O}} 0.0476$ & 0.0837 & 0.0657 \\
\hline $\mathrm{Ba}$ & $3010 \mathrm{~A}, 7060 \mathrm{~B}$ & 0.01 & 0.05 & 3.78 & 3.86 & 3.82 \\
\hline $\mathrm{Cd}$ & $3010 \mathrm{~A}, 7060 \mathrm{~B}$ & 0.01 & 0.05 & ${ }^{\mathrm{J}} 3.13 \times 10^{-3}$ & ${ }^{\mathrm{U}} 1.29 \times 10^{-3}$ & $2.21 \times 10^{-3}$ \\
\hline $\mathrm{Cr}$ & $3010 \mathrm{~A}, 7060 \mathrm{~B}$ & 0.01 & 0.05 & 0.186 & 0.306 & 0.246 \\
\hline $\mathrm{Pb}$ & $3010 \mathrm{~A}, 7060 \mathrm{~B}$ & 0.025 & 0.1 & 0.0357 & 0.0757 & 0.0557 \\
\hline $\mathrm{Hg}$ & $7470 \mathrm{~A}$ & $6 \times 10^{-4}$ & $2 \times 10^{-3}$ & ${ }^{\mathrm{J}} 1 \times 10^{-5}$ & ${ }^{\mathrm{U}}<6 \times 10^{-4}$ & $1 \times 10^{-5}$ \\
\hline $\mathrm{Se}$ & $3010 \mathrm{~A}, 7060 \mathrm{~B}$ & 0.06 & 0.15 & ${ }^{\mathrm{J}} 0.0753$ & 0.0608 & 0.0681 \\
\hline $\mathrm{Ag}$ & $3010 \mathrm{~A}, 7060 \mathrm{~B}$ & 0.01 & 0.05 & ${ }^{\mathrm{U}}<0.01$ & $\mathrm{U}_{<0.01}$ & $<0.01$ \\
\hline
\end{tabular}

- Indicates a location in the table for which an entry would not be appropriate.

${ }^{\mathrm{U}}$ Final concentration of the analyte was found to be below the DL.

${ }^{J}$ Analyte is present at a concentration above the DL but less than the RL.

$<$ DL Used when reported value is less than zero.

\subsection{Comparison of Results to Regulatory Limits}

Results from the TCLP leachate analyses from Table 3 are replicated in Table 4 along with the regulatory limits that may be applied to the Saltstone waste form. Table 4 includes the SCHWMR R.61-79.261.24(b) limits above which a waste is to be considered characteristically hazardous for toxicity and the SCHWMR R.61-79.268.40 Universal Treatment Standards (UTS) for hazardous constituents. In addition, Maximum Contaminant Levels (MCLs) from the State Primary Drinking Water Regulations ${ }^{\dagger}$ also have been included in Table 4.

By comparing the sample results and the regulatory limits in Table 4, the following conclusions can be made:

- The Tank 50 Batch 0 Saltstone waste form was not characteristically hazardous for toxicity.

- The leachate metals concentrations were below the Nonwastewater Standard for all eight of the metals.

- The leachate metals concentrations were below the MCLs for cadmium, mercury and silver.

The TCLP leachate RCRA metal concentrations were well below the SCHWMR R.6179.261.24(b) limits for characteristically hazardous toxic waste. Similarly, all results were less than the UTS Nonwastewater Standard. None of the analyses were greater than 10x the MCL.

$\dagger$ Regulations 61-58 through 61-58.15 are promulgated pursuant to S.C. Code Sections 44-55-10 et

seq. and are collectively known as the State Primary Drinking Water Regulations. 
Table 4 Saltstone TCLP Results and Corresponding Regulatory Limits.

\begin{tabular}{|c|c|c|c|c|}
\hline- & Sample Results & \multicolumn{3}{|c|}{ Regulatory Limits (mg/L) } \\
\hline- & Average & Toxicity $^{\mathrm{a}}$ & $\mathrm{UTS}^{\mathrm{b}}$ & $\mathrm{MCL}^{\mathrm{c}}$ \\
\hline Date & - & - & \multirow{3}{*}{$\begin{array}{c}\text { Nonwastewater } \\
\text { Standard } \\
\text { (mg/L TCLP) }\end{array}$} & - \\
\hline SRS ID & - & - & & - \\
\hline GEL ID & - & - & & - \\
\hline As & 0.0657 & 5 & 5 & 0.010 \\
\hline $\mathrm{Ba}$ & 3.82 & 100 & 21 & 2 \\
\hline $\mathrm{Cd}$ & $\mathrm{U}_{2.21 \times 10^{-3}}$ & 1 & 0.11 & 0.005 \\
\hline $\mathrm{Cr}$ & 0.246 & 5 & 0.6 & 0.1 \\
\hline $\mathrm{Pb}$ & ${ }^{\mathrm{J}} 0.0557$ & 5 & 0.75 & $0.015^{\mathrm{d}}$ \\
\hline $\mathrm{Hg}$ & ${ }^{U} 1 \times 10^{-5}$ & 0.2 & 0.025 & 0.002 \\
\hline $\mathrm{Se}$ & 0.0681 & 1 & 5.7 & 0.05 \\
\hline $\mathrm{Ag}$ & $\mathrm{U}_{<0.01}$ & 5 & 0.14 & $0.1^{\mathrm{e}}$ \\
\hline
\end{tabular}

- Indicates a location in the table for which an entry would not be appropriate.

${ }^{\mathrm{U}}$ Final concentration of the analyte was found to be below the DL.

${ }^{J}$ Analyte is present at a concentration above the DL but less than the RL.

${ }^{a}$ R.61-79.261.24(b) "Characteristic of Toxicity".

${ }^{\mathrm{b}}$ R.61-79.268.40 "Universal Treatment Standards".

${ }^{\mathrm{c}}$ SCDHEC State Primary Drinking Water Regulation Maximum Contaminant Levels.

${ }^{\mathrm{d}}$ Lead action level from SCDHEC 61-58.11.B.

${ }^{\mathrm{e}}$ Secondary drinking water parameter.

\subsection{Quality Assurance}

The following subsections include summaries of results from blanks, laboratory control samples, matrix spikes, and matrix spike duplicates. The data package for this task also includes data for calibration verifications, interference checks, and serial dilutions.

\subsubsection{Blanks}

Blank concentrations are given in Table 5. No analytes were detected in the Method Blank. In the TCLP Tumbling Blank, barium and chromium were present at levels above their DLs, but below their RLs. The Method Blanks analyzed with this Sample Delivery Group (SDG) met the acceptance criteria.

Table 5. RCRA Metal Method Blank and TCLP Tumbling Blank.

\begin{tabular}{|c||c||c|}
\hline Analyte & Method Blank $(\mathrm{mg} / \mathrm{L})$ & Tumbling Blank $(\mathrm{mg} / \mathrm{L})$ \\
\hline \hline $\mathrm{As}$ & ${ }^{\mathrm{U}} 6.37 \times 10^{-3}$ & ${ }^{\mathrm{U}} 1.02 \times 10^{-2}$ \\
\hline $\mathrm{Ba}$ & $\mathrm{U}^{\mathrm{U}} 2.31 \times 10^{-4}$ & 0.011 \\
\hline $\mathrm{Cd}$ & $\mathrm{U}^{\mathrm{U}}-1.72 \times 10^{-3}$ & ${ }^{\mathrm{U}}-1.17 \times 10^{-3}$ \\
\hline $\mathrm{Cr}$ & ${ }^{\mathrm{U}} 9.57 \times 10^{-3}$ & ${ }^{\mathrm{J}} 0.0114$ \\
\hline $\mathrm{Pb}$ & $\mathrm{U}^{\mathrm{U}}-1.75 \times 10^{-4}$ & $\mathrm{U}^{\mathrm{U}}-1.63 \times 10^{-2}$ \\
\hline $\mathrm{Hg}$ & $\mathrm{U}_{-}-6.21 \times 10^{-4}$ & $\mathrm{U}^{\mathrm{U}}-3.53 \times 10^{-4}$ \\
\hline $\mathrm{Se}$ & ${ }^{\mathrm{U}} 2.3 \times 10^{-2}$ & ${ }^{\mathrm{U}} 5.4 \times 10^{-2}$ \\
\hline $\mathrm{Ag}$ & $\mathrm{U}_{-}-2.32 \times 10^{-3}$ & $\mathrm{U}^{\mathrm{U}}-4.12 \times 10^{-3}$ \\
\hline
\end{tabular}

${ }^{U}$ Final concentration of the analyte was found to be below the DL.

${ }^{\mathrm{J}}$ Analyte is present at a concentration above the DL but less than the RL. 


\subsubsection{Laboratory Control Samples}

Results from the Laboratory Control Sample (LCS) are given in Table 6. All LCS recoveries met USEPA SW-846 acceptance limits. Laboratory Control Samples are clean aqueous solutions analyzed to assure integrity of the analytical technique exclusive of matrix effects.

Table 6. RCRA Metal Laboratory Control Sample.

\begin{tabular}{|c||c|c||c|}
\hline Analyte & \multicolumn{2}{|c||}{ Laboratory Control (mg/L) } & Recovery (\%) \\
\hline- & True & Measured & - \\
\hline \hline $\mathrm{As}$ & 50.0 & 52.2 & 104 \\
\hline $\mathrm{Ba}$ & 100 & 107 & 107 \\
\hline $\mathrm{Cd}$ & 10.0 & 10.6 & 106 \\
\hline $\mathrm{Cr}$ & 50.0 & 52.6 & 105 \\
\hline $\mathrm{Pb}$ & 50.0 & 53.6 & 107 \\
\hline $\mathrm{Hg}$ & 0.020 & 0.0206 & 103 \\
\hline $\mathrm{Se}$ & 10.0 & 10.1 & 101 \\
\hline $\mathrm{Ag}$ & 5.00 & 5.33 & 107 \\
\hline
\end{tabular}

\subsubsection{Matrix Spikes}

Results from analysis of the matrix spike (MS) and matrix spike duplicates (MSD) are given in Table 7. These results show that:

- The percent recoveries (\%R) obtained from the MS analyses are evaluated when the sample concentration is less than four times (4X) the spike concentration added. All applicable elements met the acceptance criteria.

- The percent recovery $(\% \mathrm{R})$ obtained from the MSD analyses are evaluated when the sample concentration is less than four time (4X) the spike concentration added. All applicable elements met the acceptance criteria.

- The RPD(s) between the MS and MSD met the acceptance limits.

Table 7. TCLP Leachates RCRA Metal Matrix Spike and Duplicate Results.

\begin{tabular}{|c|c|c|c|c|c|c|c|}
\hline Analyte & \multicolumn{2}{|c|}{$\begin{array}{l}\text { Initial Concentrations } \\
(\mathrm{mg} / \mathrm{L})\end{array}$} & \multicolumn{2}{|c|}{$\begin{array}{l}\text { Spiked Sample } \\
(\mathrm{mg} / \mathrm{L})\end{array}$} & \multicolumn{2}{|c|}{ Recovery (\%) } & $\begin{array}{l}\mathrm{RPD} \\
(\%)\end{array}$ \\
\hline- & $\begin{array}{l}\text { GEL ID } \\
179997001\end{array}$ & $\begin{array}{l}\text { Spike } \\
\text { Added }\end{array}$ & Spike & $\begin{array}{c}\text { Spike } \\
\text { Duplicate }\end{array}$ & Spike & $\begin{array}{c}\text { Spike } \\
\text { Duplicate }\end{array}$ & - \\
\hline As & $\begin{array}{c}{ }^{\mathrm{U}} 0.0476 \\
\end{array}$ & 50.0 & 53.8 & 53.8 & 108 & 107 & 0 \\
\hline $\mathrm{Ba}$ & 3.78 & 100 & 108 & 108 & 105 & 104 & 0 \\
\hline $\mathrm{Cd}$ & $\mathrm{U}_{3.13 \times 10^{-3}}$ & 10.0 & 10.4 & 10.5 & 104 & 105 & 1.0 \\
\hline $\mathrm{Cr}$ & 0.186 & 50.0 & 52.1 & 52.1 & 104 & 104 & 0 \\
\hline $\mathrm{Pb}$ & J 0.0357 & 50.0 & 52.6 & 52.6 & 105 & 105 & 0 \\
\hline $\mathrm{Hg}$ & ${ }^{0} 1 \times 10^{-5}$ & 0.020 & 0.0221 & 0.0218 & 110 & 109 & 1.4 \\
\hline $\mathrm{Se}$ & 0.0753 & 10.0 & 10.5 & 10.5 & 104 & 104 & 0 \\
\hline $\mathrm{Ag}$ & ${ }^{U}-2.26 \times 10^{-3}$ & 5.00 & 5.50 & 5.51 & 110 & 110 & 0.2 \\
\hline
\end{tabular}

${ }^{U}$ Final concentration of the analyte was found to be below the DL.

${ }^{\mathrm{J}}$ Analyte is present at a concentration above the DL but less than the RL. 
WSRC-STI-2007-00260

Revision 0

\subsubsection{Calibration Information}

- All initial calibration requirements have been met for this sample delivery group (SDG).

- All Contract Required Detection Limit standard(s) met the referenced advisory control limits.

- All interference check samples associated with this SDG met the established acceptance criteria.

- All continuing calibration blanks bracketing this batch met the established acceptance criteria.

- All continuing calibration verifications bracketing this SDG met the acceptance criteria.

\subsection{CONCLUSIONS}

Preparation of the Tank 50H Batch 0 saltstone samples and the subsequent TCLP analyses showed that:

- The Tank 50H Batch 0 Saltstone waste form was not characteristically hazardous for toxicity.

- The leachate metals concentrations were below the Nonwastewater Standard for all eight of the metals.

- The leachate metals concentrations were below the MCLs for cadmium, mercury and silver.

- Analyses met all quality assurance specifications of USEPA SW-846.

The Tank 50H Batch 0 saltstone met the SCHWMR R.61-79.261.24(b) RCRA metals requirements for a nonhazardous waste form. The TCLP leachate concentrations were less than 10x the MCLs in SCDHEC Regulations R.61-107.16, Subpart A, 16.5.

Analyses met all USEPA SW-846 quality assurance requirements. This included limits on holding times, laboratory control sample recoveries, matrix spike recoveries, serial dilution results when applicable, calibration verification, and interference checks. 


\subsection{REFERENCES}

1 “Saltstone Grout Sampling (U),” ESH-EPG-2004-00318, K.R. Liner (2004).

2 "Confirmation of Saltstone Grout Formulation for Batch 0," SSF-TTR-2006-0001, Rev. 0 (2006).

3 "Tank 50 Batch 0 Saltstone Formulation Reconfirmation Using Samples Collected in September 2006 (U)," WSRC-TR-2006-00226, C.A. Langton, E.K. Hansen, P.R. Burket, D.M. Marsh and D.P. Healy (2006).

${ }^{4}$ E-mail from J.W. Ray to A.D. Cozzi, 12/12/2006.

5 "Characterization of Tank 50H Material Per Saltstone Waste Acceptance Criteria Analysis Requirements-2006," WSRC-TR-2006-00320, L.N. Oji and S. McCollum, (2006).

6 “Toxic Characteristic Leaching Procedure," Method 1311, EPA Manual SW-846 (1992).

7 "GEL Data Package for TCLP Analyses of Tank 50 Saltstone", SRNL-PSE-200700116, A.D. Cozzi (2007). 